\title{
Efforts to Improve English Speaking Ability of Five to Six-Years-Old Bilingual School Students Through Hand Puppet Media
}

\author{
Nila Fitria ${ }^{1, *}$, Atria Farastiwi ${ }^{2}$ \\ ${ }^{1,2}$ University of Al Azhar Indonesia, Indonesia \\ *afarastiwi@gmail.com
}

\begin{abstract}
This classroom action research was motivated by the five to six-year-old students' low English speaking ability in bilingual schools, especially in pronouncing, adding vocabulary, and forming sentences. This research aims to improve the English language skills of five to six-year-old students using hand puppets. This research was conducted from April 9 to May 4, 2018, at the TK IT Al Ikhlas Islamic Bilingual School by employing Kemmis's and Mc Taggart's model in two cycles with three meetings each. The subjects of this research consisted of twelve students (seven males and five females). Based on the research results, there was an increase in English language skills through hand puppet media. In conclusion, the factors affecting students' English speaking skills are familiar vocabulary, clear and easy to imitate teacher's pronunciation, exciting and varied media, and opportunities for them to use hand puppets while imitating the teacher. The researchers concluded that the hand puppet media could improve the five to six-year-old students' language skills.
\end{abstract}

Keywords: speaking ability; english; hand puppet media

\section{Upaya Meningkatkan Kemampuan Berbicara Bahasa Inggris Di Sekolah Bilingual Pada Anak-Anak Berumur 5 - 6 Tahun Melalui Media Boneka Tangan}

\begin{abstract}
Abstrak
Penelitian tindakan kelas ini dilatarbelakangi oleh rendahnya kemampuan anak usia 5 - 6 tahun dalam berbicara bahasa Inggris di sekolah bilingual, terutama pada aspek pengucapan, penambahan kosakata dan pembentukan kalimat. Penelitian ini bertujuan untuk meningkatkan kemampuan berbahasa Inggris anak usia 5 - 6 tahun melalui media boneka tangan. Penelitian ini dilaksanakan pada tanggal 9 April sampai dengan 4 Mei 2018, di Sekolah Bilingual Islam TK IT Al Ikhlas. Penelitian ini menggunakan model Kemmis dan Mc Taggart yang dilaksanakan 2 siklus dimana satu siklus terdiri dari 3 pertemuan. Subjek penelitian ini adalah 12 anak, 7 anak laki-laki dan sisanya perempuan. Berdasarkan hasil penelitian diketahui bahwa terjadi peningkatan kemampuan berbahasa Inggris melalui media boneka tangan. Secara keseluruhan hasil penelitian terdapat faktor lain yang mempengaruhi peningkatan kemampuan berbicara bahasa Inggris anak, yaitu: pemilihan kosakata yang mudah dan lebih dekat dengan anak, pengucapan guru harus jelas dan mudah ditiru, penggunaan media yang menarik dan bervariasi, dan terakhir memberikan kesempatan kepada anak untuk menggunakan boneka tangan. media sambil meniru apa yang dikatakan guru. Berdasarkan hasil penelitian dapat disimpulkan bahwa media boneka tangan dapat meningkatkan kemampuan berbahasa Inggris anak usia 5 - 6 tahun.
\end{abstract}

Kata Kunci: kemampuan berbicara; bahasa inggris; media boneka tangan 


\section{INTRODUCTION}

A language is a communication tool that humans use to interact (Sari et al., 2018). Language becomes an essential element for humans in living their daily lives. Humans need language to speak, listen, read, and write to establish and expand their relationships with others. Speaking is a part of language skills besides listening, reading, and writing (Ita et al., 2020). Students' speaking ability is based on their ability to listen because they can speak well and fluently if they do not have hearing problems. Students who are fluent in speaking can communicate their ideas and ask questions (Kusdiyati, 2018). According to (Otto, 2015) listening, speaking, reading, or writing involve language process and usage. Verbal communication occurs through speaking. Through speaking, students can communicate effectively.

Five to six-year-old students have a strong desire to speak because they could express their opinions, feelings, and needs. It is used as a medium to communicate with peers and adults around them. Others must understand the articulation of words spoken by students when they express their needs and feelings so that the interlocutors can understand their intention. (Hurlock, 1980) states that speaking is a form of language that uses articulation or words to communicate the meaning.

Students' speaking ability will increase as they grow and develop. According to, students' speaking ability is the capability to apply the aspects of speech that include: 1) pronunciation, (2) grammar, (3) vocabulary, and (4) ideas and thoughts (Lindawati et al., 2018). Students' speaking ability is a result of habituation from the environment and imitation. Students learn speaking through the systems of sound, grammar, and vocabulary that they often hear at home (Alam \& Lestari, 2019). Besides with family members at home, speaking could be done by conversing with teachers or peers at school and other adults. Relationships and interactions like this can develop students' speaking ability.

Students in their early childhood period can learn words and like the challenge of learning new words. Besides Indonesian, English also needs to be introduced to students. Having the ability to speak English will benefit anyone who has it. English has become a universal communication tool and most global information sources in various aspects (Hapsari, 2014). English is an ability that can be used as added value in every day and future competition. It does not harm students to get an early English education. Current research 
consistently showed that most early childhood students could learn two languages and obtain cognitive, cultural, and economic benefits because they have dual-language skills(Santrock, 2007) Students will more easily master English if it is given early. According to Rossel \& Ross (Zaman, Badru \& Eliyawati, 2010), the earlier the child is introduced to English and the more they say it, the better they learn it.

The English achievement levels are intended to have practical and straightforward listening and speaking skills related to the learning themes (Maulidiyah, 2014). Listening and speaking ability are related because listening ability influences the development of speaking ability. Students who have an excellent speaking ability must also have an excellent listening ability. However, most students at TK IT Al Ikhlas Islamic Bilingual School could not speak well in English. Many students spoke in Indonesian to communicate with their peers, teachers, and the school environment. The bilingual program held by the school did not influence students' English speaking ability.

The researcher tried to observe students' speaking ability, especially during the English lessons. The English lessons were held every two days with five school days. Based on the observations, the students, particularly in class B3, could not speak English well. There were only three out of twelve students who could mention two to three words in English. Some students were confused between one vocabulary to the others. Most students could not form complete and straightforward sentences in English sequentially. These problems were interesting because five to six-year-old students who attend bilingual schools could not speak English well.

Improving students' English speaking ability can be done by creating conditions that allow them to talk and be heard by talking, telling stories, role-playing, singing, playing together, sightseeing, and questioning. The use of learning media is also highly recommended to improve learning quality, especially in language learning. By applying learning media, students' motivation and interest in learning can be improved. Besides, hand puppets media are easy to use, just by putting hands inside the puppet and moving the puppet's head, mouth, and hands. The hand puppet is the most straightforward puppet to be used by kindergarten students. They typically do not have the skills to operate limbed-puppets. The application of hand puppets can develop students' verbal language skills, improve their memory, and develop their creative potential (Oktaviana et al., 2014). 
Based on the explanation, the researcher tried to improve the English language skills of five to six-year-old students using hand puppets. The researcher decided the title of this research as "Efforts to Improve English Speaking Ability of Five to Six-Years-Old Bilingual School Students Through Hand Puppet Media." Based on the background, the identified problems were (1) the high frequency of Indonesian compared to English, resulting in students' low English speaking ability. (2) The methods and media used in learning were inappropriate to develop English speaking ability.

According to Mappadjantji (Prabawa \& Kumalasari, 2020) a school is a learning community where administrators, teachers, and students learn and work together to achieve success. Furthermore, there are three types of early childhood education services: formal, nonformal, and informal. Law of Indonesian Republic, Number 137 of 2014 concerning the national standard of early childhood education (Chapter I, Article 1, and point 11), states that early childhood education (PAUD) programs are early childhood education services carries out by educational institutions in the form of Kindergarten (TK), Raudhatul Athfal (RA), Bustanul Athfal (BA), Play Group (KB), Child Care Centers (TPA), and allied early childhood education units (SPS).

Weinrich(Hoffmann, 2014) states that the practice of alternately using two languages will be called bilingualism, and the person involved is bilingual. The theory explains that a bilingual is someone who uses two languages while using two languages called bilingualism. According to (Freeman, 1998), bilingual education means using two languages for instructional purposes.

Based on the explanation, a bilingual school is a formal education that applies one type of bilingual educations in learning activities. However, the actual application of bilingual schools is consistently used in two languages, both English and Indonesian, during learning activities. However, not every bilingual school applies the same bilingualism. Some schools apply bilingualism by emphasizing languages, first language, and target language, or their first language is more dominant than the target language. Some schools apply the second language as a separate subject. Even though every bilingual school is not the same, all have the same goal: to help students have life skills by developing other languages.

According to (Otto, 2015), there are five types of programs for second language learners, namely: (1) English as Second Language (ESL), which is a program that is focused only on teaching English. A student's first language is not considered and is not used in any 
aspect of learning. Teachers in the ESL program may not have the knowledge or fluency in a student's first language. This approach aims to foster English acquisition so that students can participate in English instruction. (2) Bilingual Education consists of two types of educations, namely: transitional bilingual education and bilingual developmental education. Both of these approaches are used in the class where students are taught by teachers who fluent in both languages. In the beginning, teachers use students' first language in giving instructions. English is taught as a separate subject, then gradually introduced and used in giving instructions. Transitional bilingual education aims at the gradual transition from a student's first language into English. Furthermore, bilingual developmental education is almost similar to transitional bilingual education. Both languages are used in giving instructions. However, transitional bilingual education emphasizes both languages during students' education, so fluency in the first language and foreign language can be developed and maintained. (3) Immersion Program is a program where students are grouped according to their first language. Teachers in the immersion class must have fluency in students' first language and English. Linguistic learning is given in the first language. At the same time, other learning in the class curriculum is given in a second language. There are two types of immersion programs: the two-type immersion program and the second foreign language immersion program. The twotype immersion program or dual language program is a learning program designed to develop linguistic skills in more than one language. There are variations in how this two-type immersion program is organized. Here, English is gradually used until each language usage reaches $50 \%$ every day. The comparison between the uses of the first language and the second language for kindergarten to third grade is $80: 20$, from the fourth grade to the sixth grade is 60:40, and from the seventh grade to the eighth grade is 50:50. The second foreign language is designed for students with a majority language, such as native English speakers. (4) The submersion Approach is applied when a school does not have a bilingual program for second language learners. The students can be placed in public classes along with other students whose first language is English. Teachers in this class do not have to be bilingual and specially trained. (5) Foreign Languages in the Elementary School/FLES is a program that emphasizes rote learning, training patterns, and grammar with fewer success rates than a program that emphasizes cultural knowledge and verbal communication. One of the main factors in the FLES program is using the target language in a communicative situation and condition at school or community. 
Based on the explanation, it can be concluded that the acquisition of a second language is almost similar to the first language development and does not harm early childhood. Students who acquire a second language after three years old are called successive bilinguals. At first, students who get a second language pronounce one word, followed by two words, until then says in many words. The vocabulary which is introduced should not be too difficult, and the words taught should be familiar to the students so that the students can understand easily. The second language acquisition process, especially in learning English, begins when the students hear the words spoken by the teacher through his sense of hearing because students' language develops through listening activities. Then, the students directly imitate the utterances, although not as perfect as when they utter them. Giving English learning itself must be well planned by using the proper methods and media.

Otto summarizes several theories from experts regarding which factors could influence a person's second language acquisition. According to (Otto, 2015) three main factors significantly influence second language acquisition: student characteristics, social conditions, and linguistic input. The following is a description of the three main factors. (1) In student characteristics, age is a significant factor in second language acquisition. Students learn languages more quickly than adults. Collier concludes that eight to twelve-year-old students learn a second language faster than four to seven-year-old students. The reason that might cause this difference, according to Baker in Otto's book, is older students who have higher cognitive functions and a more developed first language, both of which help with second language acquisition. Other additional variables in students that can influence a second language acquisition include student cognitive abilities, personality, motivation, selfconfidence, and mother tongue skills. Student cognitive abilities influence how language input is processed. Personality, motivation, and confidence levels determine how students are involved in language interactions. Someone who is shy and lacks confidence will be less active in language interaction when compared to confident students. Students' first language provides the basis for how the second language is obtained. Without starting from the first language ability, second language acquisition will be complex. Second language students specifically have a "silent" period when they are in the process of gaining receptive language knowledge. During this silent period, students take on the role of an observer and remember several phrases and sentences. This behavior does not indicate a problem but must be understood as part of how to communicate in a new language. (2) The social conditions allow 
the interactions between the speakers and language targets. It is an essential factor in second language acquisition. Social conditions can be described in three variables: the role of a second language learner as an active listener or participant; the presence of concrete references, which contribute to symbol formation and conceptual development; and people who show the target language. (3) Students must understand linguistic Inputs. Understandable input occurs when speakers use the second/target language at a level that slightly exceeds the listener's level of understanding. Is linguistic input could be understood as a result of the interaction between the intensity and quality of the target language received by second language learners. For example, in a class that focused on text-based instruction, plus a lack of teacher linguistic awareness, a lack of experiential learning, and a level of fluency in English as a second language, students might not accept the comprehensible input needed for language learning.

Based on the description above, it can be concluded that various factors can influence the acquisition of a second language. It is also seen that each of the factors mentioned has a relationship with each other. However, from several opinions above, these factors can be classified into two internal and external factors. Internal factors originate from the child's self, such as age, gender, health, cognitive abilities, and personality of the child. At the same time, the external factor in the form of a child's environmental situation is whether it supports acquiring a second language. Briggs(Suhartono, 2005) mentions that the media is essentially physical equipment to bring or perfect the teaching content. Media in the learning process can enhance the student learning process in learning, which is expected to enhance learning outcomes (McDevitt et al., 2010). Furthermore, in (Arsyad, 2011) Levie \& Lentz put forward four functions of learning media, especially visual media, namely: attention function, affective function, cognitive function, and compensatory function. The explanation of the four functions includes: (1) Attention function means that the media is the core, attracting and directing the attention of students to concentrate on the content of the lesson; (2) Affective Function means that the media can be seen from the level of enjoyment of students when learning; (3) Cognitive Function means the media facilitates the achievement of goals to understand and remember information or messages contained in the media; (4) Compensatory Function means that the media helps students who are weak and slow to accept or understand the contents of the lesson to organize information and recall it. 
Seels and Glasgow(Ngadino, 2009) classified media into two broad categories based on technological developments: traditional media and the latest media. Traditional media choices include visual media, silent and projected, non-projected visual media, audio media, multimedia presentation, projected dynamic visual media, print media, game media, and concrete media such as models, specimens, manipulative (maps, puppets). At the same time, the choice of the latest technology media includes telecommunications-based media and microprocessor-based media. (Nana Sudjana, 2016) mentions what is meant by hand puppet moved by hands. (Beaty, 2019) states that students think of making hand puppets talks with their mouths than speak by themselves. The use of hand puppets is also able to improve memory, creativity, and speaking abilities.

The hand puppet itself is the most accessible puppet to be used by kindergarten students. Kindergarten students typically do not have the skills to operate limbed-puppets. (Bronson, 1995) states that the most accessible first puppets are sock or mitten. Students typically do not have the dexterity to operate limbed-puppets. Besides, hand puppets can also develop students' verbal language skills, train their memory, and help their imagination. Learning activities are more fun with hand puppets media to attract and direct students' attention. By using hand puppet media in learning English, it is expected to increase students' motivation and learning interest so that the students can listen well to the teacher's explanations.

\section{RESEARCH METHOD}

The research was conducted at TK IT Al Ikhlas Islamic Bilingual School located at Jalan Sasak Jikin RT. 06/03 Jati Murni, Pondok Melati, Kota Bekasi. The research was conducted in the second semester of 2017/2018 from March to June 2018. The subjects of this research were TK IT Al Ikhlas Islamic Bilingual School's students, especially in group B because their age was in the range of five to six years old. The subjects consisted of twelve students.

This research was classroom action research (CAR).(Arikunto, 2010) states that classroom action research examines learning activities in the form of action deliberately showed and occurred together in a classroom. The data collection techniques employed were observation, interviews, and documentation. The observation was done during the English learning process. The interview questions were asked to the principal and the teachers of 
group B regarding the process of English learning and their opinions related to students' English speaking ability.

The instruments employed in this research were observation sheets with pronouncing, adding vocabulary, and forming sentences as the indicators. The data were analyzed using qualitative and quantitative descriptive analysis techniques. The observation sheet data were presented in the form of a descriptive narrative. Also, the researcher carried out simple statistical calculations to measure the scores and percentages of students' English speaking ability, both before and after the application of hand puppets. The obtained data were processed to obtain the percentage and average score (Farida et al., 2020; Pratiwi et al., 2021). In this research, the researchers calculated the completeness percentage according to completeness criteria contained in the following table:

Table 1. Completeness Criteria

\begin{tabular}{cc}
\hline Percentage of Completeness & Classification \\
\hline$>\mathbf{8 0}$ & Excellent \\
$\mathbf{7 0 0}-\mathbf{8 0}$ & High \\
$\mathbf{4 0}-\mathbf{6 0}$ & Moderate \\
$>\mathbf{2 0}-\mathbf{4 0}$ & Low \\
$\leq \mathbf{2 0}$ & Poor \\
\hline
\end{tabular}

(Pratiwi et al., 2021)

The data percentages were analyzed using the following formula (Farida et al., 2020; Pratiwi et al., 2021) :

$\mathrm{P}=\frac{\mathrm{F}}{\mathrm{N}} \times 100 \%$

Description:

$\mathrm{P}=$ Percentage Number

$\mathrm{F}=$ Activity Frequency/Students' Score

$\mathrm{N}=$ Number of Students in One Class

Based on the completeness criteria, the success criteria in this research can be declared successful if at least $75 \%$ of students obtained a score of 3 on each of the assessment indicators. The researchers expect this research to improve the English speaking ability of the five to six-year-old students of class B3 at TK IT Al Ikhlas Jati Murni. 


\section{RESULT AND DISCUSSION}

\section{A. Result}

This research was conducted within one month from April 9, 2018, to May 4, 2018. Furthermore, this research was conducted in two cycles with three meetings in each cycle. English lesson at TK IT Al Ikhlas Islamic Bilingual School is held as a separate subject.

The average percentage of students who got a 3 in the first cycle is $44,1 \%$ in pronouncing indicator, $41,3 \%$ in adding vocabulary indicator, and $32,1 \%$ in forming sentences indicator. Although there were improvements of each indicator in cycle I, the score had not reached the success criteria set by the researcher, which was $75 \%$. Thus, the researchers felt the need to conduct cycle II.

The researchers faced several obstacles when applying hand puppet media in the first cycle. The students did not respond to the English learning process because the learning materials were new with too many vocabularies. The students could not speak English to answer questions posed by the teacher regarding the learning theme. The number of hand puppets media prepared did not match the number of students; therefore, there was a commotion because they wanted to use the same hand puppets. Also, the teacher explained the material too quickly that several students could not understand. The solutions to the mentioned problems are: reduce the number of vocabulary, encourage the students by giving rewards to anyone who wants to answer questions, explain the material slowly, and control the situation to allow the students to speak English through hand puppets media.

The average percentage of students who got the score 3 in cycle II is $76,9 \%$ in pronouncing indicator, $76,9 \%$ in adding vocabulary indicator, and $70,4 \%$ in forming sentences. Compared to the average percentage of cycle I, class B3's English speaking ability increased to the expected criteria. The data can be seen in the table and diagram below :

Table 2. The Improvement Percentage on Each Cycle

\begin{tabular}{ccccc}
\hline No. & Assessment & Cycle I & Cycle II & Improvement \\
& Indicators & Results & Results & \\
\hline 1. & Pronouncing & $44,1 \%$ & $76,9 \%$ & $32,8 \%$ \\
2. & Adding Vocabulary & $41,3 \%$ & $76,9 \%$ & $35,6 \%$ \\
& & & & $38,3 \%$ \\
3. & Forming Sentences & $32,1 \%$ & $70,4 \%$ & \\
\hline
\end{tabular}




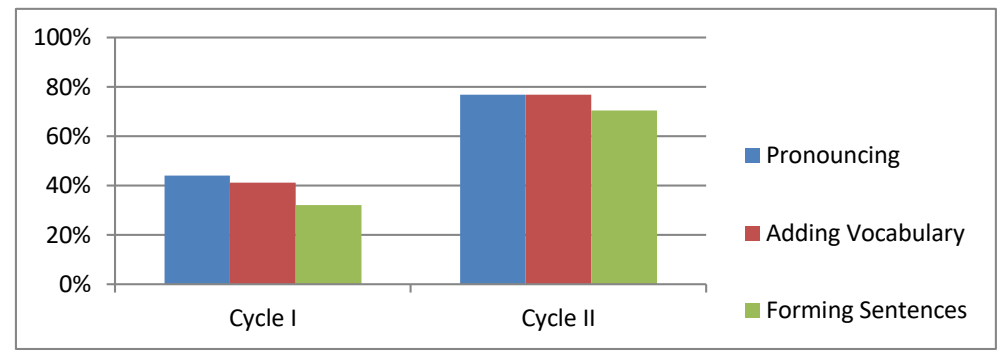

Figure 1. The Improvement Percentage on Each Cycle

\section{B. Discussions}

Based on the obtained data, it can be said the actions were successful. The increase happened because of the application of hand puppet media. The students could remember several kinds of professions-related vocabulary introduced by the teacher. When the teacher held a questions and answers session with the students using hand puppet media, most students correctly named the type of professions in English and formed simple English sentences. (Beaty, 2019) proposes that students make the hand puppets talk using their mouths. Besides, the application of hand puppets could improve students' memory, creativity, and speaking ability. However, other factors influence students' English acquisition as their second language. (Otto, 2015) states that three main factors significantly influence second language acquisition: student characteristics, social conditions, and linguistic input. Although the students were in the same class in this research, they had varied language development because their ages were different. Students' first language ability also affects both Indonesian and English processing. The intensity of students' involvement in interactions and confidence in English also influences English acquisition. If the students are shy and lack confidence, they will be less active in language interaction than confident students. The teachers are also influential in students' Indonesian and English language acquisition.

\section{CONCLUSIONS AND SUGGESTIONS}

Based on the results of data analysis, there was an increase in students' English speaking ability after using hand puppet media. Therefore, it can be said that the improvement of students' English speaking abilities (pronouncing, adding vocabulary, and forming sentences) significantly increased through hand puppet media. This increase happened 
because of the selection of familiar and standard vocabularies. Also, the teacher's pronunciation was clear and easy to imitate. Using a hand puppet in introducing some vocabularies and telling stories, students listened well to what the teacher said. Furthermore, the students were allowed to use hand puppet media and imitate what the teacher said. Then, the teacher introduced questions and answers sessions related to the vocabulary and the story.

Based on the conclusions, it is suggested for the teachers to have clear, correct, and easily imitated pronunciation. The hand puppet usage should be well-planned by adjusting to the learning theme. Also, it is best to use one learning media so that students can focus on that media. It is recommended that the principal improve the teachers' teaching skills in using hand puppets in English to improve student's English speaking ability. It is recommended that further researchers give more attention to the hand puppet, which will be used in the learning process by considering the themes, especially the professions theme. Further researchers can add accessories to the hand puppet according to the profession to understand the introduced profession well.

\section{ACKNOWLEDGMENT}

Thanks to the Islamic Bilingual School TK IT Al Ikhlas for giving permission to conduct research. Thank you to the Al Azhar University PG PAUD study program for supporting this research.

\section{REFERENCES}

Alam, S. K., \& Lestari, R. H. (2019). Pengembangan Kemampuan Bahasa Reseptif Anak Usia Dini dalam Memperkenalkan Bahasa Inggris melalui Flash Card. Jurnal Obsesi : Jurnal Pendidikan Anak Usia Dini, 4(1), 284. https://doi.org/10.31004/obsesi.v4i1.301 Arikunto, S. (2010). Penelitian tindakan. Yogyakarta: Aditya Media. Arsyad, A. (2011). Media Pembelajaran. PT Raja Grafindo Persada. Beaty, J. J. (2019). Observasi perkembangan anak usia dini.

Bronson, M. B. (1995). The Right Stuff for Children Birth to 8: Selecting Play Materials To Support Development. ERIC.

Farida, Pratiwi, D. D., Andriani, S., Pramesti, S. I. D., Rini, J., Wkuswanto, C., \& Sutrisno, E. (2020). Development of Interactive Mathematics E-Module Using Visual Studio. Journal of Physics: Conference Series, 1467(1). https://doi.org/10.1088/17426596/1467/1/012017

Freeman, R. D. (1998). Bilingual education and social change (Vol. 14). Multilingual Matters.

Hapsari, A. R. C. (2014). Pembelajaran Matematika Anak Usia 7 - 8 Tahun dengan Menggunakan Program Imersi di Sekolah Bilingual Bina Mulia. School Bekasi. Jakarta: 
Skripsi Universitas Al Azhar Indonesia.

Hoffmann, C. (2014). Introduction to bilingualism.

Hurlock, E. B. (1980). Psikologi perkembangan. Jakarta: Erlangga.

Ita, E., Wewe, M., \& Goo, E. (2020). Analisis Perkembangan Kemampuan Bahasa Anak

Kelompok A Taman Kanak-Kanak Anak Usia Dini. Al-Athfaal: Jurnal Ilmiah

Pendidikan Anak Usia Dini, 3(2), 174-186.

Kusdiyati, S. (2018). Pengaruh Pemberian Dongeng Dengan Boneka Tangan Terhadap

Kemampuan Berbahasa Indonesia. Psympathic : Jurnal Ilmiah Psikologi, 3(2), 157-168. https://doi.org/10.15575/psy.v3i2.2184

Lindawati, N. P., Asriyani, R., \& Anggayana, I. W. A. (2018). MODEL KOOPERATIF THINK-PAIR-SHARE DALAM MENINGKATKAN KEMAMPUAN MENULIS KARANGAN DIALOG BAHASA INGGRIS MAHASISWA AKADEMI KOMUNITAS MANAJEMEN PERHOTELAN INDONESIA. Director, 4(1), 39-50.

Maulidiyah, H. (2014). Bahasa Inggris untuk Taman Kanak-kanak (Silabus dan Panduan Guru). malang.

McDevitt, T. M., Ormrod, J. E., Cupit, G., Chandler, M., \& Aloa, V. (2010). Child development and education. Merrill Upper Saddle River, NJ.

Nana Sudjana. (2016). Penilaian Hasil Proses Belajar Mengajar. Bandung : PT Remaja Rosdakarya.

Ngadino, Y. (2009). Pengembangan Media Pembelajaran. Surakarta: Pendidikan Profesi Guru FKIP UNS.

Oktaviana, W., Wiarta, I. W., \& Zulaikha, S. (2014). Penerapan Metode Bercerita Berbantuan Media Boneka Tangan Untuk Mengembangkan Kemampuan Berbahasa Lisan Pada Anak kelompok B Semester Genap TK Kumara Loka Denpasar. Jurnal Pendidikan Anak Usia Dini Undiksha, 2(1).

Otto, B. (2015). Perkembangan bahasa pada anak usia dini. Jakarta: Kencana.

Prabawa, F. R., \& Kumalasari, D. (2020). School Well-being SD Konvensional dengan SD Alam. Penelitian Psikologi, 11(2), 49-56.

Pratiwi, D. D., Mujib, Andriani, S., Mardiyah, Kuswanto, C. W., \& Utami, E. (2021). Application of algebraic tile media with gasing: Ability to understand mathematical concepts and student creativity. IOP Conference Series: Earth and Environmental Science, 1796(1). https://doi.org/10.1088/1742-6596/1796/1/012023

Santrock, J. W. (2007). Psikologi Pendidikan edisi kedua. Kencana Prenada Media Group.

Sari, R. P., Suryani, N. A., \& Imran, R. F. (2018). Peningkatan Kemampuan Membaca Permulaan Dengan Menggunakan Metode Bermain Flash Card Subaca. Al-Athfaal: Jurnal Ilmiah Pendidikan Anak Usia Dini, 1(2), 36-55. https://doi.org/10.24042/ajipaud.v1i2.3741

Suhartono. (2005). Pengembangan Keterampilan Bicara Anak Usia Dini. Jakarta: Departemen Pendidikan dan Kebudayaan Direktorat Jenderal Pendidikan Tinggi, Direktorat Pembinaan Pendidikan Tenaga Pendidikan dan Ketenagaan Perguruan Tinggi.

Zaman, Badru \& Eliyawati, C. (2010). Bahan Ajar Pendidikan Profesi Guru (Media Pembelajaran Anak Usia Dini). Bandung: Jurnal Pendidikan Guru Pendidikan Anak Usia Dini Universitas Pendidikan Indonesia. 